\title{
AZ EDELÉNYI JÁRÁS MUNKAERŐPIACI HELYZETÉNEK VIZSGÁLATA
}

\author{
Sipos Levente - Szűcs Antónia
}

\section{Összefoglalás}

Az. elmuilt évtizedekben jelentôsen megváltozott a demográfiai, társadalmi és gazdasági helyzet az. ország egyes régióiban. Az országon belül kialakult területi különbségek elmélyülése fokozódó problémákhoz vezetett az ország bátrányos belyzetü régióiban. Vizsgálati terïletünk az Észak-magyarországi régióban, Borsod-Abaúj-Zemplén megyében található Edelényi járás, mely egyike hazánk legelmaradottabb, leghátrányosabb helyzetü térségének. Kutatási célunk megismerni a járásban élō munkavállalók munkaerópiaci helyzetét, az azt befolyásoló és meghatározó tényezöket. Szekunder kutatás mellett primer kutatás során feltártuk az, ott élök igényeket, elvárásait, mellyel megfogalmazhatók olyan megoldási lehetöségeket, melyek hoz:ájárulhatnak abhoz, hogy egy élhetöbb, jól szervezett térség jöhessen létre, ahol az emberek élete megfelelö színvonalra fejlödhetne, ezáltal mérséklödne a térségben jelen lévô munkanélküliség, javulna a térség bátrányos helyzete is.

Kulcsszavak: hátrányos helyzetü térségek, munkanélküliség, Edelényi járás, területfejlesztés

JEL: R10

\section{EXAMINATION OF THE LABOR MARKET SITUATION OF THE EDELÉNYI DISTRICT}

\begin{abstract}
The demographic, social and economic situation in some regions of the country has changed significantly in recent decades. The deepening of territorial disparities within the country has led to increasing problems in disadvantaged regions of the country. Our study area is the Edelenyi district in the region of Northern Hungary, Borsod-AbauijZemplén county, which is one of the most backward and disadvantaged areas in Hungary. Our research goal is to get to know the labor market situation of the employees living in the district and the factors influencing and determining it. In addition to secondary research we explored the needs and expectations of the people living there with a primary research first, which lead us to possible solutions contributing to a more livable and a well-organized region where the inhabitants' life could develop to a higher standard. In this way the present unemployment figures could be reduced and the disadvantages of the whole region would also improve.
\end{abstract}

Keywords: disadvantaged areas, unemployment, Edelényi district, regional development JEL: R10 


\section{Bevezetés}

A munkaerôpiac keresleti és kínálati tényezői együttesen hatással vannak a foglalkoztatás színvonalára, a munkanélküliségre, és a reálbér-egyensúlyi bér viszonyán keresztül a bérek, keresetek, a javadalmazás színvonalára és a munkaerő nemzetgazdasági szintű allokációjára, eloszlására (Csehné, 2011). Világszerte és így hazánkban is nagy probléma a munkanélküliség, mely kialakulhat leépítések, elbocsátások következtében, de az okok között a pályakezdőknél előforduló elhúzódó keresés is előfordulhat (Hajduska, 2008). Hazánkban az 1989-90-ben bekövetkező politikai és gazdasági rendszerváltás miatt a megváltozott feltételek szükségessé tették a foglalkoztatáspolitikai eszközrendszer átalakítását, korszerű, piacgazdasági elveken alapuló törvény megalkotását. A gazdaság átalakulása szükségszerűen maga után vonta a társadalom átalakulását is. Új társadalmi csoportok jelentek meg: a munkanélküliek és hajléktalanok. Földrajzi értelemben is hatalmas változások történtek. Az országon belül óriási egyenlőtlenségek alakultak ki. Míg hazánk egyes vidékei virágoznak, fejlődnek, addig más vidékei jelentôs nehézségekkel, hátrányokkal néznek szembe. Az ország infrastrukturálisan gyengén ellátott területein ezrek munkaviszonya szűnt meg egyik napról a másikra, és egyre magasabb számban jelentek meg a munkanélküliek. Ezen változások a területek fokozatos leszakadását, és az itt élők elszegényedését okozták (Sági, 1997). A gazdasági térben a fejlett és fejletlen térségek egyidejü jelenléte komoly társadalmi, gazdasági feszültségeket okoz, és megnehezíti a hátrányos helyzetű térségek integrálódását (Balcsók, 2005). Számos munkanélküli nem, vagy csak késve tud reagálni a megváltozott munka- és életfeltételekhez, melynek az lehet a következménye, hogy alulmaradnak a munkaerőpiaci versenyben (Benedek, 2001; Hajdú, 2021). A munkanélküliség legszembetűnőbb következménye gazdasági szinten jelentkezik, hiszen a rossz anyagi helyzetet hosszú távon szegénységet okozhat, és az anyagi tartalékok felélése egyre nyomasztóbb terhet jelent a családok számára is (Albert et al. 2003).

A legfontosabb célkitǔzés a hátrányos helyzet miatt adódó különbségek kiküszöbölése, megoldások keresése e célból (G. Fekete, 2006, Dávid et al, 2008). Hátrányos helyzetű csoportok és területek mindazok, melyek az országos átlaghoz viszonyítva rosszabb gazdasági - társadalmi- szociális helyzetben vannak. A leghátrányosabb és ezen belül a komplex program kidolgozására jogosult térségek támogatására a kormány 2008-ban külön programot - LHH Program (2008- 2013) - indított, melynek fő célja az LHH- s járások, települések felzárkóztatása, vagy legalább a leszakadás megállítása a különböző EU- s támogatások felhasználásával, támogatásával. Az LHH Program az Európái Bizottság stratégiai jelentésében jó gyakorlatként szerepelt, ezért folytatódott a hátrányos helyzetű térségek támogatása (2014- 2020), ahol Partnerségi Megállapodásban jelölték meg az LHH programban résztvevő alapokat, operatív programokat és azok támogatási körét (Edelényi Paktum, 2019). Hazánk a területfejlesztési uniós támogatások elérhetôsége végett két nemzeti szintű fejlesztési tervet is készített, melynek legfontosabb célkitűzése a foglalkoztatás bővítése és a tartós növekedés feltételeinek megteremtése volt (Bujdosó, 2016). Több alprogram a különböző hátrányos helyzetű csoportok munkaerőpiaci integrációját célozta képzésekkel, bértámogatással és innovatív foglalkoztatáspolitikai eszközökkel (Hajdú - Koncz, 2021).

Jelen kutatásunk során az alábbi hipotézisek érvényesülését vizsgáltuk:

- Hipotézis (H1): A járás területén élő emberek az ország egyik leghátrányosabb helyzetben lévő munkavállalói, akiknek megnehezíti a munkaerőpiacon való elhelyezkedésüket lakóhelyük földrajzi elhelyezkedése, a térségben fellelhető vállalkozások, munkalehetőségek alacsony száma. 
- Hipotézis (H2): A térségben magas az alacsonyan képzett vagy képzettség nélküli hátrányos helyzetű munkavállalók száma, mely megnehezíti ezen társadalmi rétegeknek a munkaerőpiacon való elhelyezkedésüket.

- Hipotézis (H3): Az itt élő emberekben megvan a szándék arra, hogy dolgozzanak, javíthassanak nehéz helyzetükön, és hajlandóság mutatkozik képzéseken való részvételre.

\section{Anyag és módszer}

Szekunder kutatásunk során a KSH és az Edelényi Járási Hivatal Foglalkoztatási Osztálya adatbázisaira támaszkodtunk. A primer kutatásunkhoz nem reprezentatív, véletlenszerü mintavételen alapuló kérdőíves felmérést végeztünk 120 fő bevonásával. A mintavételre személyesen és online módon került sor 2020. júliusában. A települések kiválasztásánál a lakónépesség számát, valamint a járás területén belüli elhelyezkedést vettük figyelembe.

A vizsgált Edelényi járás Borsod- Abaúj-Zemplén megye északi aprófalvas térségében, a magyarszlovák államhatár mellett található (1. ábra). Területe: $718 \mathrm{~km}^{2}$, népessége 34031 fô, népsűrűsége 46 fö $/ \mathrm{km}^{2}$ a 2018-as KSH adatok alapján. A járás területén 45 település található, melyek a Bódva folyó és mellékpatakjainak völgyében helyezkednek el.

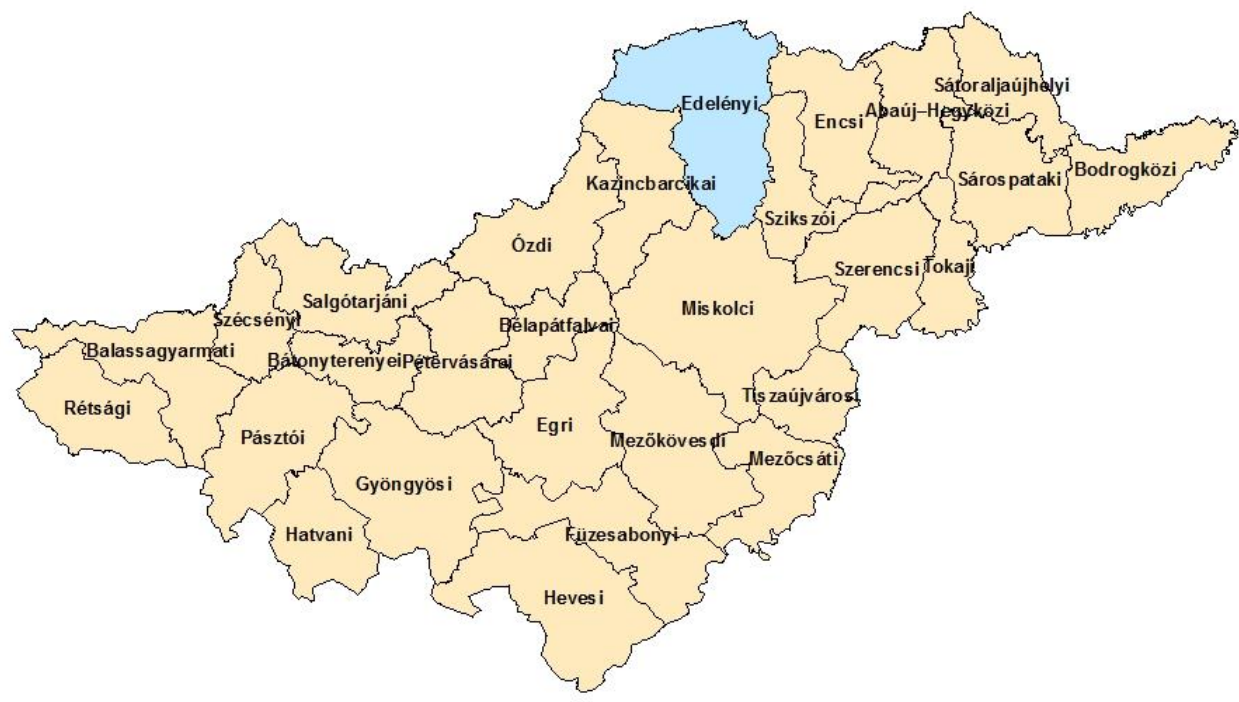

1. ábra. Az Edelényi járás elhelyezkedése az Észak-magyarországi Régión belül Forrás: saját szerkesztés 
A járás területén csupán két település, Edelény - a járás székhelye - és Szendrő rendelkezik városi ranggal. A két városban él a lakosság 41\%-a. Edelényben 9516 fő, Szendrőben 4249 fó lakost tartanak nyilván. A községek között sok az ún. zsáktelepülés (pl. Tornabarakony, Teresztenye, Égerszög, Tornakápolna), melyek mindössze egy bekötőúton kapcsolódnak be a települések rendszerébe. Ezek megközelítése és elérhetősége nagyon rossz (Edelényi Paktum, 2019). Az Edelényi járás a 290/2014. (XI.26.) kormányrendelet alapján Borsod-Abaúj-Zemplén megye 10 komplex programmal fejlesztendő járásának egyike, míg a 105/2015. (IV.23) Kormányrendelet 2. sz. melléklete alapján - mely tartalmazza azokat a településeket, amelyek elmaradottságuk és/vagy munkanélküliségük szerint a kedvezményezett települések közé tartoznak- társadalmi, gazdasági és infrastrukturális szempontból kedvezményezett településeinek száma 29, jelentős munkanélküliséggel sújtott településeinek száma 21, míg mindkét szempontból 18 település érintett (Koós- Virág, 2012).

\section{Eredmények}

\section{Szekunder kutatás eredményei}

A demográfiai mutatókat a népességszám-változását a természetes népmozgalmi adatok, valamint a vándorlási egyenleg együttesen alakítja. A demográfiai folyamatok nagymértékben befolyásolják egy területi egység munkaerő-potenciálját, foglalkoztatási lehetőségeit. A járás kedvezőtlen demográfiai helyzetét igazolja a lakosság számának folyamatosan csökkenése. A népszámlálási adatok szerint 2000-ben a járás népessége 37431 fö, 2010-ben 35447 fö, míg 2019-ben már csak 34031 fő. Ebben közre játszik a természetes szaporodás változása, az elvándorlások magas aránya, az egyre öregedő társadalom együttesen. A természetes szaporodás tekintetében a járásban az élve születések és a halálozások száma a vizsgált időszakban jelentôs eltérést nem mutat. Az élve születések száma 2014-ben ugyan meghaladta a halálozásokét, valamint minimális különbséggel a 20182019- es évben is magasabbnak mutatkozott a születések száma, de ezen adatok közötti eltérés nem számottevő. Az egyes települések népességszám-változása nagyon változatos képet mutat. Egyes településeken (Tornanádaska, Bódvalenke, Szendrőlád, Szin) a születési arányszám ugyan magas, míg máshol (Debréte, Tornabarakony, Teresztenye) nagyon alacsony. A természetes szaporodás elsősorban azokon településeken pótolja a természetes fogyást, ahol a népességen belül igen magas a roma népesség aránya, vagyis a magas születési szám elsősorban a cigányság magas gyermekvállalási hajlandóságából fakad, míg a kritikusan alacsony születésszámú településeket pedig az idős, csökkenő népességű aprófalvak alkotják. Vannak olyan települések, ahol már évek óta nem született gyermek. A térségből folyamatos az elvándorlás. Csupán 2012-ben volt tapasztalható, hogy magasabb volt az odavándorlások száma, mint az elvándorlásoké.

A járás munkaerőpiaci viszonyait vizsgálva elmondható, hogy a hazánkban is jelenlévő munkanélküliség problémája az ország hátrányos helyzetủ településeit és ott élő munkavállalóit még erőteljesebben érinti. Igaz ez az Edelényi járás munkavállalóira is. A járás területén korábban a megélhetést jelentő két kiemelten fontos ágazat a mezőgazdaság és a bányászat volt. 1995-ben azonban a bányák sorra zárták be kapuikat, megszűnt a Termelőszövetkezet, és több, mint 2000 ember veszítette el a munkahelyét és ezeket a hiányosságokat azóta nem igazán sikerült pótolni. A térségben 2796 db regisztrált és 1074 db működő vállalkozást tartottak nyilván 2015-ben. A múködő vállalkozások esetében elmondható, hogy túlnyomó többségük mikro vállalkozás, azaz 10 fő alatti létszámot foglalkoztat. 500 fő feletti nagyvállalat nincs a térségben, és a kis-és középvállalkozások aránya is nagyon alacsony. 
Az Edelényi járás területén 20637 fő munkaképes korú lakos él. A regisztrált munkanélküliek (álláskeresők) száma 2010-ben 4818 fö, 2016-ban 2129 fő, 2019-ben 2283 fő volt. A munkanélküliek száma 2012-ben volt a legmagasabb, és 2018-ban a legalacsonyabb. Ez az ingadozás részben a természetes munkaerőpiaci folyamatoknak, részben a bevezetett közfoglalkoztatási rendszernek köszönhető.

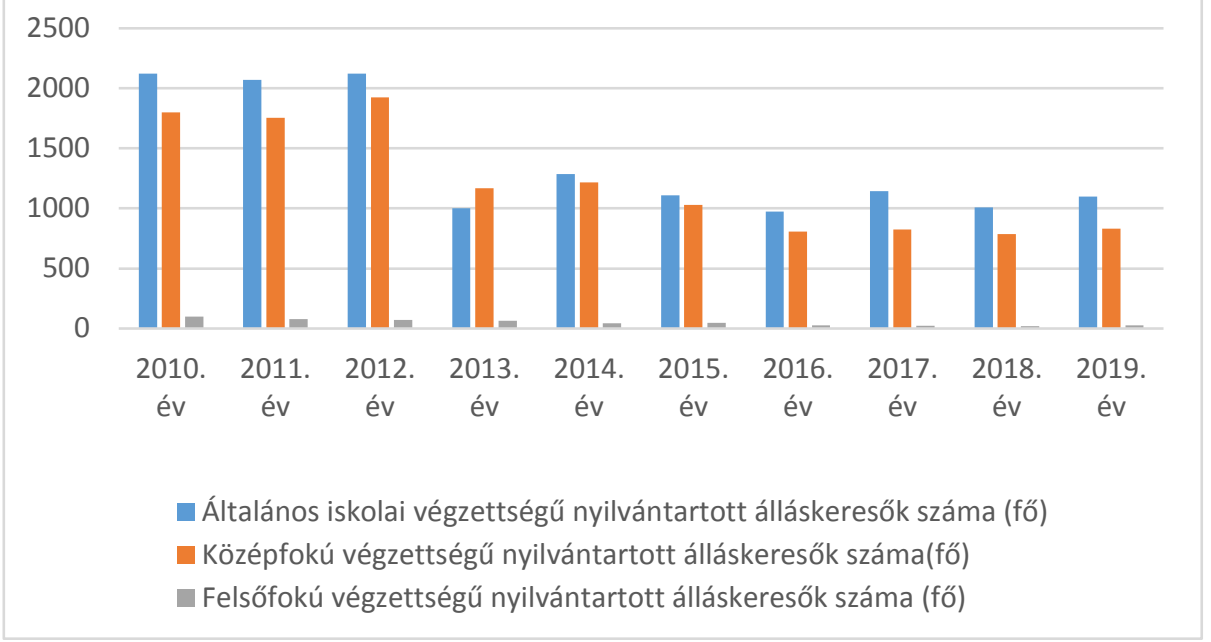

\section{2. ábra. Álláskeresők iskolai végzettség szerinti megoszlása 2010-2019}

Forrás: Edelényi Paktum (2019) alapján saját szerkesztés

Az álláskeresők, munkanélküliek számát nagyban meghatározza az iskolai végzettségük, képzettségük megléte vagy éppen hiánya. A térségben az alapfokú végzettségú álláskeresők aránya a legmagasabb, ami mutatja, hogy az iskolai végzettség alacsony szintje nehezíti a járás munkavállalóinak munkaerőpiacon való elhelyezkedését (2. ábra). Emellett a középiskolai végzettségủek is jelen vannak az álláskeresők között. A felsőfokú végzettségűek viszonylag kedvező helyzetben vannak a járás munkaerôpiacán. Ők azok, akik a járásban fellelhető kevés munkalehetőséget nagyobb eséllyel kapják meg, ugyanakkor ők azok, akik jobb lehetôségek reményében hajlamosak elhagyni a térséget és így nem jelennek meg az álláskeresők nyilvántartásában.

A járásban a munkaerőpiaci helyzet javulását nagyban befolyásolja a közfoglalkoztatási rendszer jelenléte, múködése a járás településein. A közfoglaltatás helyzetét vizsgálva látható, hogy a közfoglalkoztatottak száma a vizsgált időszakban folyamatosan növekedett. Míg 2013-ban a közfoglalkoztatási ráta 33,96\% volt, addig 2017 -re ez az érték már elérte a majdnem 60\%-ot, ami magasnak mondható a 2013-as évhez viszonyítva (1. táblázat). A közfoglalkoztatásban általában az alacsonyan képzett, alacsony iskolai végzettséggel rendelkezők, - többségükben „roma munkavállalók” - vesznek részt, - akiket a szakirodalmi megfogalmazás munkaerőpiaci szempontból hátrányos helyzetű munkavállalóként nevez meg.

1. táblázat. Közfoglalkoztatásban résztvevők havi átlagos létszáma (2013-2017)

\begin{tabular}{|l|c|c|c|c|c|}
\hline \multicolumn{1}{|c|}{ Edelényi járás } & 2013. & 2014. & $\mathbf{2 0 1 5 .}$ & $\mathbf{2 0 1 6 .}$ & $\mathbf{2 0 1 7 .}$ \\
\hline $\begin{array}{l}\text { Hosszabb idôtartamú köz- } \\
\text { foglalkoztatás támogatása } \\
\text { (fó) }\end{array}$ & 363 & 1246 & 1302 & 1836 & 1908 \\
\hline $\begin{array}{l}\text { Országos közfoglalkozta- } \\
\text { tási program támogatása } \\
\text { (fó) }\end{array}$ & 335 & 404 & 568 & 601 & 395 \\
\hline
\end{tabular}




\begin{tabular}{|l|c|c|c|c|c|}
\hline $\begin{array}{l}\text { Járási startmunka minta- } \\
\text { program támogatása ösz- } \\
\text { szesen (fö) }\end{array}$ & 1352 & 1287 & 1258 & 1355 & 1120 \\
\hline Mindösszesen & $\mathbf{2 0 5 0}$ & $\mathbf{2 9 3 7}$ & $\mathbf{3 1 2 9}$ & $\mathbf{3 7 9 3}$ & $\mathbf{3} \mathbf{4 2 3}$ \\
\hline $\begin{array}{l}\text { Közfoglalkoztatási mutató } \\
(\%)\end{array}$ & 8,77 & 12,62 & 13,53 & 17,44 & 15,93 \\
\hline $\begin{array}{l}\text { Közfoglalkoztatási ráta } \\
(\mathbf{0})\end{array}$ & $\mathbf{3 3 , 9 6}$ & $\mathbf{3 3 , 9 6}$ & $\mathbf{5 2 , 5 6}$ & $\mathbf{5 9 , 8 6}$ & $\mathbf{5 8 , 3 9}$ \\
\hline
\end{tabular}

Forrás: Edelényi Paktum (2019) alapján saját szerkesztés

\section{Primer kutatás eredményei}

A kérdőív kitöltésére vállalkozó személyek között a nem szerinti megoszlás az alábbiak szerint alakult: 51 fő férfi, 69 fő. A válaszadók a 18- 66 év közötti korosztályból kerültek ki. Közülük 3 fő tanuló, 2 fő gyeden lévő munkavállaló, míg 1 fő nyugdíjas. A beérkezett válaszokból állandó munkaviszonnyal 72 fő rendelkezik, közülük 8 fő vállalkozó, 26 fő közfoglalkoztatottak, 16 fô álláskereső- munkanélküli. Nyugdíjas 1 fő, tanuló 3 fő, 2 fő pedig gyesen van jelenleg.

A válaszadók iskolai végzettségéről megállapítható, hogy nagyon kevés, csupán 9 fő felsőfokú végzettségü. Középiskolai végzettséggel 43 fő, szakmunkás végzettséggel 36 fő rendelkezett. Azok, akiknek nincs vagy 8 általános iskolai végzettsége van, azok száma 32 fő.

A jövedelmi viszonyokat vizsgálva megállapítható, hogy a megkérdezettek jövedelmi szintje alacsony. Csupán 10 fó nyilatkozott úgy, hogy az egy főre jutó jövedelme $200 \mathrm{E}$ Ft vagy a fölötti. Legmagasabb arányt azok képviselik, akiknek jövedelme 51-100 E Ft között mozog, (41 fó), de vannak olyanok is, (40 fö), akiknek jövedelmi szintje $50000 \mathrm{Ft}$ alatti.

A válaszadók legmagasabb arányát a mezőgazdaságban dolgozók képviselik (35fő), majd őket a kereskedelemben és vendéglátásban dolgozók követik (33fő). Az építőiparban 22 fő, míg a közszférában 10 fő dolgozik. Egyéb tevékenységet 4 fő jelölt meg, akik közül 3 fô tanuló 1 fő nyugdíjas, valamint 16 fő jelölte meg, hogy nem dolgozik sehol.

A válaszadók többsége a fizikai munkát jelölte meg (83 fö). Ez kapcsolatba hozható azzal, hogy a térségben jelenlévő vállalkozások többsége, az építőipar, vendéglátás, kereskedelem, mezőgazdaság, mind olyan tevékenységet végző vállalkozások, melyeknek fő tevékenysége fizikai munkavégzéssel párosul és a munkavállalók képzettségi szintje, a térség adta lehetőségek is befolyásolják a munkavégzés jellegét. A szellemi foglalkoztatottak száma nagyon alacsony, csupán 21 fó.

A megkérdezettek közül 44 fő elégedettséget jelölt meg, míg 72 fő elégedetlen jelenlegi munkaerőpiaci pozíciójával. Az elégedetlenség megjelenhet a munkavégzés és a munkabér aránytalanságában, a képzettségnek nem megfelelő munkavégzésben, illetve a munkahely és lakóhely közötti távolságban egyaránt.

A válaszadók, többségében (64 fö) nem a szakképzettségüknek megfelelő munkát végzik, hanem a térségben vagy akár azon kívül adódó lehetőségeket kihasználva vállalnak, végzettségüknek nem megfelelő munkát.

A megkérdezettek közül csupán 6 fő dolgozik a lakóhelyén. A közmunkaprogramban részt vevő személyek között is többen az önkormányzati társulások végett más (szomszédos) településeken végeznek közmunkát. A megkérdezett munkavállalók nagy része (114 fö) naponta több km-t tesz meg, több órát is utazik más - járáson belüli vagy kívüli - településekre munkavégzés céljából (3. ábra). 


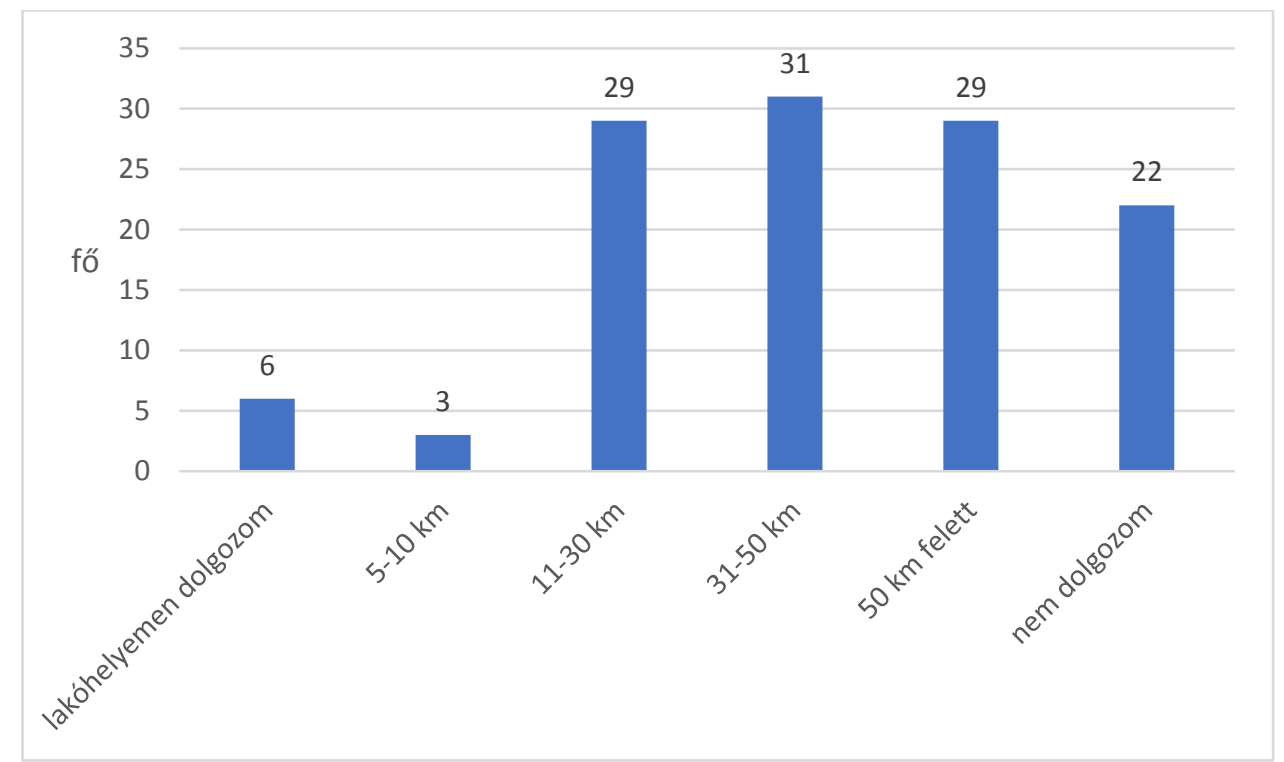

\section{3. ábra. A válaszadók lakóhelye és munkahelye közötti távolság $(\mathrm{km})$}

Forrás: saját számitás, $N=120$ (2020)

A megkérdezettek közül 27 fő nyilatkozott úgy, hogy hajlandó lenne a járás más településére költözni, 38 fő akár az ország más vidékére, 12 fő pedig akár külföldi munkát is hajlandó lenne vállalni. A megkérdezett 36\%-a nyilatkozott úgy, hogy nem szeretne elköltözni. Ők valójában azon személyek lehetnek, akik megszokták itteni életüket, szeretik lakóhelyüket, és valószínúleg rendelkeznek olyan megélhetéssel, jövedelmi szinttel, mely biztosítja itt maradásukat. Ezzel szemben a másik ok lehet, ami a járásban élőket itt tartja, a „rossz” anyagi helyzetük.

A megkérdezettek közül 106 fő jelölte meg, hogy szívesen részt venne képzésekben és azok közül is 56 fő az OKJ képzést részesítette előnybe (4. ábra). Valószínúleg azért, mert abban bíznak, hogy az ilyen képzések által olyan szakképzettséget szerezhetnek, melyekkel el tudnának helyezkedni a munkaerőpiacon. Érettségizni 32 fő szeretne, és az általános iskolai képzést 1 fő jelölte meg. A válaszadók között 14 fő az, aki nem kíván részt venni semmilyen képzésben.

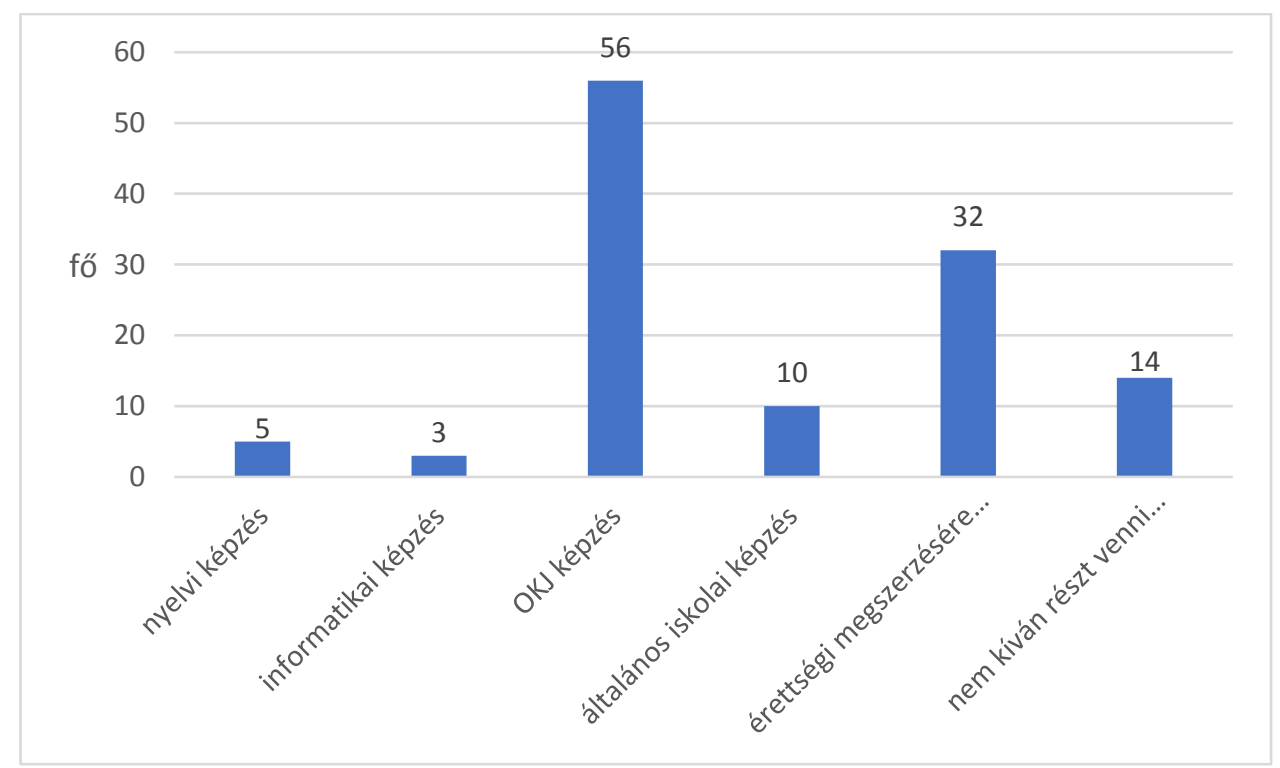

4. ábra. A válaszadók képzéssel kapcsolatos igényei

Forrás: saját sqámitás, N=120 (2020) 
A válaszadók szerint 32 fó úgy nyilatkozott, hogy a közmunka program nem jelent segítséget a munkanélküliek számára, míg 7 fő nem tudta megítélni ezt a helyzetet. A megkérdezettek többsége (81 fö) szerint azonban a közmunkaprogram átmenetileg segítséget jelent a munka nélkül maradt egyének számára. A közmunka programban általában az alacsonyan képzett munkaerő vesz részt, de akadnak olyanok, akár magasabb iskolai végzettséggel rendelkezők, akiknek megszűnt a munkahelye, és átmenetileg nem tudnak, vagy nem is akarnak a térségtôl távol eső munkahelyre utazni (családanyák), vagy más megélhetési forrással rendelkeznek, és emiatt nem igénylik a közmunkában való részvételt még átmeneti segítségként sem.

A válaszadók elsô helyen legnagyobb problémának a járásban jelenlévő munkanélküliséget jelölték meg, vagyis a munkanélküliek magas számát, majd ezt követi az etnikum magas száma és az alacsonyan képzett munkaerő, a munkalehetőségek hiánya a térségben (5. ábra). Ugyanakkor a fiatalok elvándorlását, az infrastrukturális hiányosságokat nem tartják különösebb problémának, pedig a lakónépesség számának csökkenése és az infrastrukturális hiányosságok is jelen vannak a járás hátrányos helyzetének okozói között. Valószínúleg ez a megkérdezettek lakóhelyén nem jelent problémát, vagy nem érzik annak. Ugyanakkor az is szemmel látható, hogy a járás több településén az utóbbi években számos infrastrukturális fejlesztés történt, de a kisebb falvakban még így is hatalmas elmaradottság tapasztalható (Tornabarakony, Varbóc, Szőlősardó, Martonyi, Rakaca).

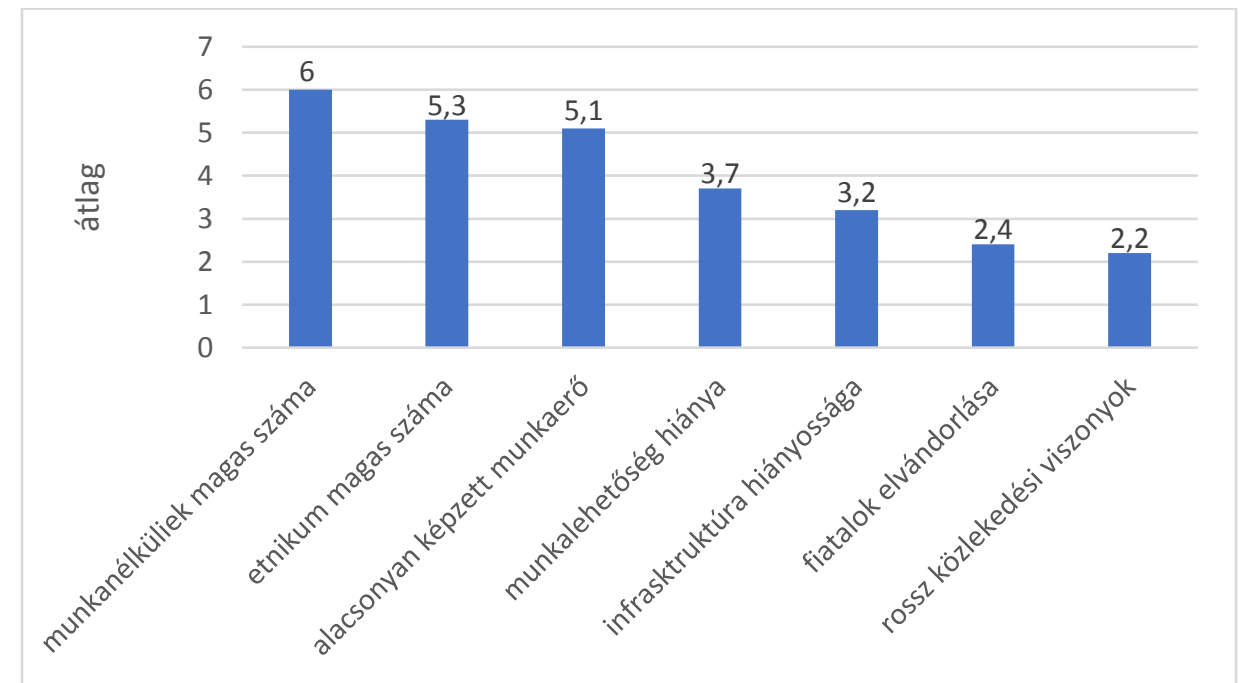

\section{5. ábra. A megkérdezettek véleménye a járásban fellelhető problémákról \\ Forrás: saját sqámitás, $N=120$ (2020)}

\section{Következtetések és javaslatok}

Az egyes településeket - főleg aprófalvakat - az elnéptelenedés, az elöregedő társadalom problémája fenyegeti, és ehhez társul még a romák által lakott települések magas száma- (szegregációs szigetek) - melyek hatással vannak a térség munkaerőpiaci helyzetére, gazdasági életére is. A munkaerőpiaci viszonyokat vizsgálva a nagyfokú munkanélküliség oka, hogy nincs megfelelő mennyiségű rendelkezésre álló munkahely, kevés a működő vállalkozások száma. A vállalkozások főként a mezőgazdaság, építőipar, a kereskedelem-vendéglátásra területére koncentrálódnak, és ezek is kis létszámban foglalkoztatják az itt élő munkavállalókat. A tömeges foglalkoztatást biztosító ipari vállalkozások szinte teljes hiánya jellemzi a térséget. A zömében, városhiányos, aprófalvas településekből álló 
térségben gyakori, hogy a kisebb településeken csak a falu életét irányító, kiszolgáló közintézmények múködnek, melyek csak csekély létszámú munkavállalót tudnak foglalkoztatni. Emiatt a munkavállalóknak naponta ingázniuk szükséges munkájuk, megélhetésük végett a térség más településeire, sok esetben a térségen kívüli városokba. Ezen megállapítások alapján elmondható, hogy első hipotézisünk beigazolódott. A térségben fellehető munkalehetőségek főleg azoknak kedvezhetnek, akik megfelelő szintű iskolai végzettséggel, képzettséggel rendelkeznek, hiszen a képzettségi szint jelentôsen befolyásolja a munkavállalók munkaerőpiacon való elhelyezkedését. Második hipotézisünk a járási hivatal adatai és a kérdőíves felmérés alapján is beigazolódott, vagyis a járás területén magas számban vannak jelen az alacsonyan képzett vagy képzetlen, valamint középfokú iskolai végzettségűek, akiknek munkaerőpiacon való elhelyezkedésük e miatt nagyon nehéz. Harmadik hipotézisünk szintén beigazolódott. A megkérdezettek többsége fontosnak tartja a különböző képzésekben való részvételt. Legmagasabb számban az OKJ képzést jelölték meg a válaszadók, melyből arra lehet következtetni, hogy ezektől a képzésektôl várják a munkavállalók, hogy olyan szakmát tanulhatnak, melyek megszerzése után nagyobb esélyük lesz elhelyezkedni a munkaerőpiacon.

A munkanélküliség helyzetének javítása céljából a gazdasági szerkezet hosszú távú átalakítása szükséges. A térség munkaerôpiaci problémáinak megoldása céljából elsődleges lenne a közút hálózat fejlesztése, mely hozzájárulhat a vállalkozások vonzásához. Célszerű lenne a fejlődés érdekében a napi munkába járás, ingázás igényeihez maximálisan illeszkedő akadálymentes és fenntartható közösségi közlekedést fejlesztése, mivel a térség rossz elérhetősége, a gyenge infrastruktúra gátolja a helyi gazdaság fejlődését. A járás hátrányos helyzetű munkavállalói számára olyan hatékony segítségnyújtásra lenne szükség, mely elősegíti munkaerôpiaci integrációjukat, úgymint az atipikus foglalkoztatási formák alkalmazása. Az emberek munkavégzésre irányuló képességeit jelentősen befolyásoló tényezők az oktatás, a képzettségi szint, a meglévő szakmai ismeret, a különböző képzések, információáramlás, a technikai fejlődés. Ezen feltételek együttes megléte jelentôségteljesen emeli, illetve ezen feltételek hiánya, hátráltatja a munkába állás lehetőségét, annak gyorsaságát, illetve a megfelelő jövedelmek elérését. E célból fontos feladat a helyi munkaerőpiaci igényekhez és sajátosságokhoz illeszkedő képesség és készségfejlesztésen alapuló, szakmai ismereteket nyújtó, képzési programok szervezése, lebonyolítása. Hangsúlyt kell fektetni a munkaerő-kínálat kompetenciáinak fejlesztésére, a felnőttképzési szolgáltatások versenyképességének javítására -a gyakorlaton alapuló képzésre, mely a munkavállaló és a foglalkoztató számára is előnyökkel jár.

\section{Hivatkozott források}

[1.] Albert A. - Babocsay Á. - Biro B. - Dornai E. - Dudás E. - F. Lassú Zs. - Faragó K. Hunyady Gy. - Kiss Gy. - Kiss P. - Kovács A. - Kőrössy J. - Kulikné Láng Zs. - Lisznyai S. - Malota E. - Mérő L. (2003): A munkanélküliség lélektana. Budapest: Osiris Kiadó. [Elektronikus kiad.] Budapest: Tankönyvtár. Letöltés dátuma: 2021. 02. 11. forrás: https:/ / regi.tankonyvtar.hu/hu/tartalom/tamop425/2011_0001_520_gazdasagpszichologia/adatok.html.

[2.] Balcsók István (2005): A munkanélküliség területi egyenlótlenségei és legjellemzóbb folyamatainak alakulása az. 1992-2002 közötti idôszakban. [PhD-értekezés] Debrecen: Debreceni Egyetem Természettudományi kar. Letöltés dátuma: 2021. 02. 20. forrás: http://www.rkk.hu/rkk/publications/phd/balcsok_ertekezes.pdf. 
[3.] Benedek L. (2001): Tanácsadás munkanélkülieknek. In: Somorjai Ildikó (szerk.): Kézikönyv a szociális munka gyakorlatához. Budapest: Szociális Szakmai Szövetség, pp. 69-86.

[4.] Bujdosó Z. (2016): A turizmus és a területfejlesztés kapcsolatrendszere Magyarországon. In: Kókai S. (szerk.) A változó világ XXI. századi kihívásai: tanulmánykötet Prof. Dr. Hanusz Árpád egyetemi tanár 70. születésnapja tiszteletére. Nyíregyháza: Nyíregyházi Egyetem Turizmus és Földrajztudományi Intézet, pp. 63-76.

[5.] Csehné Papp I. (2011): Foglalkoztatáspolitika. Gödöllő: Szent István Egyetem. [Elektronikus kiad.] Budapest: Tankönyvtár. Letöltés dátuma: 2021. 02. 02 . forrás: https://regi.tankonyvtar.hu/hu/tartalom/tamop412A/2010-0019 foglalkoztataspolitika/index.html.

[6.] Dávid L. - Tóth G. - Bujdosó Z. - Herneczky A. (2007): A turizmus és a regionális versenyképesség kapcsolatának mutatói a Mátravidék példáján keresztül. Észak-magyarországi Stratégiai Füretek 4(1), 3-20.

[7.] Dávid L. - Bujdosó Z. - Tóth G. (2008): Tourism planning in the Hajdú-Bihar - Bihor Euroregion In: Süli-Zakar, I (szerk.) Neighbours and partners : on the two sides of the border Debrecen, Magyarország : Kossuth Egyetemi Kiadó pp. 323-332.

[8.] G. Fekete É. (2006): Hátrányos helyzetből előnyök? Elmaradott kistérségek felzárkózásának lehetőségei az Észak-magyarországi régióban. Észak-magyarországi Stratégiai Füretek, 3(1), 54 68.

[9.] Hajduska M. (2008): Krízislélektan. Budapest: ELTE Eötvös Kiadó.

[10.] Hajdú D. (2021): Európai Uniós forrásból támogatott munkaerő-piaci képzések területi eloszlása Borsod-Abaúj-Zemplén megyében. Studia Mundi-Economica, 8(1), 24-36.

[11.] Hajdú D. - Koncz G. (2021): Megélhetési tanulók a Borsod-Abaúj-Zemplén megyei felnőttképzésben. Területi Statisztika, 61(2), 229-254. DOI: 10.15196/TS610206

[12.] Koós B. - Virág T. (2012): Edelényi Kistérség Borsod-Abaúj-Zemplén Megye, Észak- Magyarországi Régió, Kistérségi helyzetelemzés, Edelény. p. 66.

[13.] Sági M. (1997): Társadalmi folyamatok a rendszerváltás után, Országos Közoktatási Intézet. Budapest letöltés dátuma: 2021. 01. 15. forrás: https://ofi.oh.gov.hu/tudastar/jelentes-magyar/tarsadalmi-folyamatok.

\section{Szerzők}

Sipos Levente

hallgató

gazdasági és vidékfejlesztési agrármérnök

Magyar Agrár- és Élettudományi Egyetem Károly Róbert Campus

siposlevi1997@gmail.com

Szűcs Antónia

ORCID 0000-0002-8480-1635

$\mathrm{PhD}$

adjunktus

Magyar Agrár- és Élettudományi Egyetem Károly Róbert Campus

Szucs.Antonia@uni-mate.hu

A mûre a Creative Commons 4.0 standard licenc alábbi típusa vonatkozik: $\underline{\text { CC-BY-NC-ND-4.0 }}$ 